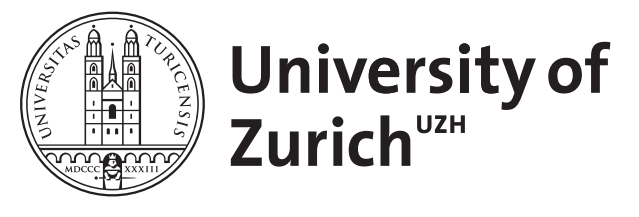

\title{
Education and the formation of geopolitical subjects
}

Müller, Martin

\begin{abstract}
Despite the crucial role of schools and universities in shaping the worldviews of their students, education has been a marginal topic in international relations. In a plea for more engagement with the power and effects of education, this paper analyzes the interplay of discipline and knowledge in the formation of geopolitical subjects. To this end, it employs material from ethnographic research at the Moscow State Institute of International Relations, the premier university for educating future Russian elites in the field of international relations. The paper draws on Foucault to chart the ensemble of disciplinary practices producing "docile bodies" and objective knowledge and traces how these practices are bound up with the geopolitical discourse of Russia as a great power: while they fashion the great power discourse with objectivity, disruptions in the discourse also disrupt disciplinary practices.
\end{abstract}

DOI: https://doi.org/10.1111/j.1749-5687.2011.00117.x

Posted at the Zurich Open Repository and Archive, University of Zurich ZORA URL: https://doi.org/10.5167/uzh-78829

Journal Article

Accepted Version

Originally published at:

Müller, Martin (2011). Education and the formation of geopolitical subjects. International Political Sociology, 5(1):1-17.

DOI: https://doi.org/10.1111/j.1749-5687.2011.00117.x 


\title{
Education and the formation of geopolitical subjects
}

\author{
Martin Müller
}

Quote as: Müller, M. 2011. Education and the formation of geopolitical subjects. International Political Sociology 5 (1):1-17.

The page numbers of this unformatted document do not coincide with those of the published original.

Universität St. Gallen

Gatterstr. 1 | 9000 St. Gallen | SWITZERLAND

martin@martin-muller.net

www.martin-muller.net

Martin Müller is Assistant Professor for Cultures, Institutions and Markets at the University of St. Gallen in Switzerland. His doctoral research combined ethnography and poststructuralist discourse theory to analyse the production of Russian geopolitical identity. Papers of his have appeared in Political Geography, Millennium: Journal of International Studies, Geopolitics and Area. 


\title{
Education and the formation of geopolitical subjects
}

\begin{abstract}
Despite the crucial role of schools and universities in shaping the worldviews of their students, education has been a marginal topic in international relations. In a plea for more engagement with the power and effects of education, this paper analyses the interplay of discipline and knowledge in the formation of geopolitical subjects. To this end it employs material from ethnographic research at the Moscow State Institute of International Relations (MGIMO), the premier university for educating future Russian elites in the field of international relations. The paper draws on Foucault to chart the ensemble of disciplinary practices producing 'docile bodies' and objective knowledge and traces how these practices are bound up with the geopolitical discourse of Russia as a great power: while they fashion the great power discourse with objectivity, disruptions in the discourse also disrupt disciplinary practices.
\end{abstract}

education; discourse; practice; ethnography; poststructuralism; great power; Russia 


\section{Introduction}

The creation of the ideal state subject - 'one schooled in the norms and proper codes of behaviour related to national citizenship' (Mitchell 2003:390) - is a central feature of education. In multiple ways, schools and universities are closely enmeshed with state formation and the education of 'good citizens', instilling loyalty to the state and patriotic thinking (e.g. Dale 1981, Green 1990, Spring 2004). Education also (re-)produces knowledge about a country's place in world politics, of geopolitical identity:

\footnotetext{
Practical geopolitical reasoning is ordinary and informal everyday discourse. It is taught in educational establishments, part of the socialization of individuals into certain 'national' identities and geographical/historical consciousnesses (Ó Tuathail 1999:114).
}

Geopolitical education, implicitly or explicitly, takes place in all kinds of educational institutions: in primary schools as well as in diplomatic academies. Even where world politics is not part of the formal curriculum, assumptions about a state's place and role in world politics are transported in the banal and not-so-banal classroom talk about 'them' and 'us', about homeland and homeland security, migration and immigration or in the use of maps and atlases.

Perhaps the most influential institutions of geopolitical education on the global level are the specialised schools of international relations, world politics and diplomacy. Teaching professional expertise, skills and codes of conduct, these establishments transmit particular knowledge about the nature and organisation of international relations. A degree from one of the leading schools, be it Columbia's School of International and Public Affairs (SIPA), the French Sciences Po or the Russian Moscow State Institute of International Relations (MGIMO), issues its holder with a passport to influential positions that allow shaping aspects of world politics. Graduates often become professionals who embark on careers in 
the foreign service of states, governments, international governmental and nongovernmental organisations, think tanks and high-level lobby firms.

Given this salient role of education in forming potential global decision-makers, it is somewhat surprising that this topic has so far received scant attention in international relations, political geography and cognate fields. In the few cases where education has featured in studies, authors have concentrated on documents such as policy briefs or text books and other educational material (e.g. Bar-Gal 1993, Herb 2004, Kuus 2009, Paasi 1999, Spring 2004). While this represents an important aspect of education, it elides the 'countless, often minor and seemingly insignificant technologies of regulation and control' (Mitchell 2003:390) within educational institutions which condition knowledge and produce subjects (Agnew 2007:143).

Getting closer to the multiple practices involved in the formation of geopolitical subjects in and through education is the central goal of this paper. It deploys ideas of Michel Foucault (1979 [1975]), seeking to move beyond the predominantly linguistic interpretations of Foucault in international relations (see Vrasti 2008:293) by drawing together language and practice (Müller 2008, Neumann 2002). For this purpose, the paper employs material from nine months of ethnographic research at the Moscow State Institute of International Relations (MGIMO), the premier university for training future Russian diplomats and elites. It shows how practices of discipline and knowledge operate at MGIMO, where they break down and in what ways their operation is tied up with the education of geopolitical subjects who identify with a strong Russia.

\section{Educating geopolitical subjects}

The philosophy of the Enlightenment sees schools and universities as critical to human emancipation. Acquiring knowledge is regarded as a necessary precondition for the 
development of the sovereign individual, the rational self who is able to transform society for the better by applying the power of reason. This position assigns to educational institutions the role of lighthouses which act as catalysts of social development (Usher and Edwards 1994). In the wake of Michel Foucault's seminal work on discipline and the nexus of pouvoir/savoir, the ideological implications of education and its contribution to subject formation have drawn considerable attention (e.g. Ball 1990, McNicol Jardine 2005, Popkewitz 1997). In contrast to scholarship in the tradition of the Enlightenment, this work foregrounds the power of education to produce subjects. For Foucault, 'every educational system is a political means of maintaining or modifying the appropriateness of discourses with the knowledge and power they bring with them' (Foucault 1971:46).

Although educational institutions often lay claim to teaching objective knowledge and skills, Agnew (2007:143) reminds us that all knowledge is 'socially conditioned by the rituals, routines, and recruitment practices of powerful educational and research institutions'. For Foucault, knowledge and power (pouvoir/savoir) are inseparable. By internalising knowledge created at schools and universities students are subjected to a disciplinary regime - a discourse with the power of producing subjectivities (Foucault 1979 [1975]:27, cf. Marshall 1990:15). Knowledge is inextricably tied to power relations because it regulates social conduct through multiple forms of constraint that all students, to varying degrees, are subjected to in educational institutions. Education thus consists of a set of organising practices which by ordering knowledge control human beings.

In his monograph Discipline and Punish Foucault develops a model of hierarchical rule that is based on technologies of observation and control. He uses the concept of 'discipline' to describe how institutions such as prisons, hospitals or schools produce 'subjected and practised bodies, "docile" bodies' (Foucault 1979 [1975]:138). In the original French, Foucault uses the verb surveiller, which points to the notion of surveillance, central to 
understanding the production of docile bodies. Educational institutions, Foucault maintains, have developed a refined arrangement of observation and control that guarantees discipline.

The activity which ensures apprenticeship and the acquisition of aptitudes or types of behaviour is developed there [in education] by means of a whole ensemble of regulated communications (lessons, questions and answers, orders, exhortations, coded signs of obedience, differentiation marks of the 'value' of each person and of the levels of knowledge) and by the means of a whole series of power processes (enclosure, surveillance, reward and punishment, the pyramidal hierarchy) (Foucault 1982:218-219).

Discipline requires that bodies are constantly observed and recorded to ensure the internalisation of institutional practices. This internalisation, however, is conditioned upon external constraints and enforcement and therefore does not create an entirely selfregulating subject.

The model of discipline, which proposes a regulation of the individual by outside forces, is a precursor to Foucault's later work on governmentality and its conceptualisation of the self-regulating individual. The idea of governmentality is often used to describe the mode of subjectivation in (neo-)liberal democracies, where power is decentred and individuals are self-governing, i.e. engage in regulation from the inside (Dean 1999, Foucault 1991). Given the prominence of the state and 'vertical power', i.e. the centralisation of power through hierarchical subordination, the modalities of societal constitution in contemporary Russia fit Foucault's concept of hierarchical rule in many ways better than the concept of governmentality. Observation and control of individuals through the state and the imposition of external constraints is a prominent feature of the government of individuals in Russia, in contrast to the self-regulation in (neo-)liberal democracies. All this points to 
the relevance of the Foucault's idea of discipline to understand subjectivation in presentday Russia.

\section{An ethnographic case study}

In order to trace the production of geopolitical subjectivity through education and its related power processes, ethnography suggests itself as the methodology of choice. In a recent turn towards giving more attention to social practices, ethnography has experienced a revaluation as a methodology in international relations and related disciplines (Eckl 2008, Jackson 2008, Megoran 2006, Pouliot 2008). However intimate an impression of subjects' lifeworlds it may give, ethnography does not afford accessing an unmediated, supposedly authentic reality. Vrasti (2008) has rightly criticised this as a fallacy which assumes that ethnography could somehow be a mimetic tool of representation. The researcher does not simply record reality that is 'out there' and give a somehow faithful rendition of it, but has to interpret her material (Jackson 2008). This involves walking the fine line, or shuttling between, participation and observation, between gaining inside knowledge and keeping a critical distance that enables interpretation (Eckl 2008, Stoddart 1986).

The trade-off, or alternation, between going-native and hands-off is one of the recurrent themes in discussions of ethnographic methodology (e.g. Fuller 1999, Harrington 2002). My in-between position as a visiting student at the Moscow State Institute of International Relations (MGIMO) provided a good starting point for my research. On the one hand, my status allowed me to blend in with other students and experience the daily routines of education, and auditing courses did not attract much attention, because it conformed to my role. On the other hand, as a Western-educated, non-native speaker of Russian who was only going to be at the university for a limited period of time, my immersion into students' 
everyday lives was inevitably also limited, enabling me to keep a measure of distance. Both are critical to establishing credibility: too little participation may compromise the validity of a researcher's account; too little distance, on the other hand, may jeopardise the critical analytical purchase. Rather than adopting a somehow neutral position, researchers come to the field with what Donna Haraway calls 'maps of consciousness': situated knowledge that is tied to one's gender, class, nationality, education and so on (Haraway 1991). Such positioning is an inevitable part of ethnography and, more than any other methodology, ethnography therefore incorporates the idiosyncratic experiences and positionality of the researcher (see Müller 2009 for more detail).

The following analysis builds on material from nine months of participant observation as a student at the Moscow State Institute of International Relations (MGIMO) in the academic year 2005/2006. While at MGIMO I kept a field diary and attended classes that were relevant to my general interest in imaginations of Russia's role in international politics. Participant observation was complemented by 39 interviews with students, mainly from the disciplines of political science and international relations, towards the end of the field research, when I had a clearer understanding of the relevant themes from the lectures, which allowed me to develop a suitable interview guide.

The remainder of the paper will initially position MGIMO as an institution of higher education in Russia and in relationship to the Russian state, before turning to an analysis of the techniques of discipline and knowledge at MGIMO, drawing on Foucault's ideas. In so doing, the paper will establish three important moments: First, the operation and the limits of discipline in education at MGIMO in producing docile bodies. Second, the processes through which knowledge is made objective and becomes truthful. Third and finally, the ways in which educational practices are tied up with the geopolitical project of a strong Russia. 


\section{Education for Russia}

The Moscow State Institute of International Relations (MGIMO) is a university under the auspices of the Russian Ministry of Foreign Affairs and acts as the premier school for education in all aspects of international politics - economic, diplomatic, legal, political. While it is primarily known for education in international relations, MGIMO has seen a rapid diversification of the student body in post-Soviet times with increasing enrolment in degrees in law, management or economics. Besides the traditional career in the state apparatus, students now take up work in the private sector or with international organisations. Notwithstanding this diversification, MGIMO's declared mission is to train elites for Russian society who are loyal to the Russian state:

It is our mission to prepare highly capable elites - opinion leaders, business captains - who can serve as a role model and who will be of use for the Russian society and our state (Rožkov 2007).

Aleksandr Losukov, ex-deputy foreign minister of Russia, reiterates that students at MGIMO 'should be taught to be patriotic, loyal to the country' (Ivanova-Galitsina 2000:8). Elite education in this vein is taken to be a central means of achieving the end of Russia's re-emergence as a great power. In the words of one professor at MGIMO:

The rise of Russia as a velikaja deržava (great power) will only be possible if education becomes one of the most important priorities in its social development. Because Russia cannot rise by selling its gas, oil and other raw materials ... but only by developing those traditions of great culture which have already contributed immeasurably to the development of global civilisation (Ašin 2002:43).

In order to prepare students for their future mission, a large part of the education at MGIMO is geared towards teaching applied knowledge and professional skills such as 
foreign languages rather than towards the education of researchers. Besides academics, MGIMO therefore also draws on practitioners, such as former diplomats or state officials, to teach classes and prepare students for their future roles as executives.

Education at MGIMO has a close connection to the Russian state and explicitly ties into the process of nation-building and promoting Russia's role as a great power. Unlike most other universities in Russia, MGIMO does not operate under the Ministry of Education and Science, but the Russian Foreign Ministry, its official name being MGIMO (University) of the Foreign Ministry of the Russian Federation. When it was established in 1944, its rationale was to create a supply of qualified diplomatic personnel for the Soviet Union's external relations and the foreign service - personnel that was supposed to not only have sound language training but also be well-versed in the ideological tenets of MarxismLeninism (Torkunov 2004). Since its inception, MGIMO has always had close connections to the circuits of power, as it provided education with the explicit purpose of creating a qualified and loyal labour pool for the Russian state apparatus. Today, as the statements above underscore, MGIMO continues to work in the interests of the Russian state, the hierarchical institutional structure with its subordination to the Foreign Ministry being an exemplar of direct rule.

Due to the high degree of centralisation of power, elites play an influential role in shaping politics and social development in Russia (Lane 1996, White 2007). This accords MGIMO an important position in educating future decision-makers that potentially influence the course of Russian politics and foreign policy. In the Soviet Union, graduation from MGIMO was tantamount to inclusion in the Soviet nomenklatura, an elite group of functionaries who held key administrative positions. This function continues today where a degree from MGIMO almost guarantees a career in the Russian state apparatus or in Russian national champions. Notable MGIMO alumni include the current Russian Minister 
of Foreign Affairs, the majority of the Russian ambassadors in the G7 states, the head of state in Azerbaijan and the oligarch Vladimir Potanin. Inclusion into the highest ranks of Russian society is also ensured by students parentage: according to a survey in 1999, more than three quarters of MGIMO students had at least one parent working in upper or middle management with the Russian state or in the private sector (Temnickij 2002).

MGIMO thus functions as an important locus for the reproduction of Russian elites. Part of this reproduction works through creating a special sense of distinction and community spirit - 'the prolonged togetherness of like-minded individuals' (Bourdieu 1996 [1989]:183) - among its students. The term Mgimovcy, a nickname for MGIMO students and graduates, serves as a marker of a common identity and sense of belonging. Bourdieu (1996 [1989]:103-128) emphasises that the reproductive function of elite schools consists in bestowing societal consecration upon their students. Almost like a rite of passage, by virtue of this consecration students are recognised as different and entitled to positions of influence.

\section{Disciplining bodies}

It is the close contact between students during their studies at MGIMO that instils a sense of community spirit and knits them together into a distinct group with bonds that often last for a lifetime and become useful in the search for jobs after graduation. Each student is assigned to one particular language group, the basic unit of educational organisation, at the beginning of her studies. Because language learning is a central component of education at MGIMO and students spend much of their study time on languages, the language groups are an arena of intense interaction. Often, it is in language groups that students find their best friends at MGIMO and develop contacts that last beyond graduation. 
Not dissimilar to school instruction, students at MGIMO have to follow a rigid timetable of classes which leaves little room to accommodate personal preferences. Timetables not only structure students' daily and weekly routines, but are the linchpin of the whole educational process at MGIMO. They are one of the first things memorised or copied into students' notebooks in the academic year. Classes usually take place in four doubles of 80 minutes each from 9 to 15.50 every day except Sunday and attendance at all classes is mandatory. Timetables list classes, times, instructors and rooms for each of the language groups and are displayed at central locations all over the MGIMO building. This allows comprehensive observation, since the timetables chart where a particular student or teacher should be and what they should be doing at any moment in time. It instructs students and lecturers when and where to go and organises their daily lives: lunch breaks, times to relax, times to study. In this vein, it functions as a central disciplinary instrument to distribute bodies in time and space without which the educational process could not function properly.

The aim of this 'disciplinary space', as Foucault (1979 [1975]:143) calls it, was to 'know where and how to locate individuals, ... to be able at each moment to supervise the conduct of each individual'. Foucault named this principle 'hierarchical observation':

\footnotetext{
The exercise of discipline presupposes a mechanism that coerces by means of observation; an apparatus in which the techniques that make it possible to see induce effects of power, and in which, conversely, the means of coercion make those on whom they are applied clearly visible (Foucault 1979 [1975]:170-171).
}

This hierarchical observation works not only through the classic model of lecturers monitoring students' academic performance, but also through students monitoring other students. Most prominently, this happens through the starosta. The starosta is a student who is in charge of monitoring the attendance and academic performance of his or her 
group. S/he usually registers present and absent students for every class and is responsible for maintaining high general attendance rates. Moreover, the starosta is also supposed to motivate the group to study hard and do the homework. At MGIMO, some departments hold competitions in which they select the group with the best academic performance. The starosta often plays the role of mediating between lecturers and students and wielding disciplinary power on part of the lecturer. It is not uncommon, for example, that a lecturer will ask the starosta to silence the class or to collect assignments. Choosing students in this way to monitor correct behaviour and ensure the smooth operation of the educational apparatus contributes towards internalising disciplinary techniques and exhorts students to become self-governing subjects.

Disciplinary expectations at MGIMO espouse the ideal of the hard-working student always busy to form herself according to the image projected onto her. Everyone is expected to strive to become one of the very best students, called otličniki. Otličniki have to constantly score very high in oral and written exams to maintain their status and receive a bonus on their stipends. Almost every department has a public notice board on which it posts its otličniki. This public posting of excellence has a normalising effect: it institutes academic performance as the central criterion for ranking students and elevates the best of the best as a model for all to see and imitate. The model student is thus scripted as a student who subjects her- or himself to the logic and primacy of academic performance by toiling to become an otličnik. Both lecturers and students are complicit with the disciplinary regime of education and contribute to its efficacy.

Control and monitoring of student's behaviour are not confined to the classroom, though. Students must be prepared to be admonished even if the timetable does not allocate them to a particular lecture hall and a particular lecture at this moment. Even outside classes, simply chatting away the time is not approved of and the principle of non-idleness is 
enforced (cf. Foucault 1979, 154). Spare time should be used to prepare for language classes or get homework done. Several times I heard curt admonitions like the following in MGIMO corridors:

Lecturer (to students standing in the corridor): "What are you loitering here? Don't you have classes?" Another lecturer: "Don't chat! Learn!"

Scholarly discipline is enforced just as much through actual surveillance as through the possibility of surveillance at unexpected moments, through the possibility of a lecturer passing by who knows you and notices your idleness.

More than distributing and controlling bodies, institutional discipline manipulates and shapes bodies in a very immediate way by establishing codes of appearance. An interview published in the career section of the popular MGIMO student magazine Majordom charts the career path of a recent MGIMO alumna, Ekaterina Karakova. The article starts with a recollection by the interviewer:

\footnotetext{
We got to know each other in the dorm; I lived with her on the same floor. She was rather short, not slim, wore glasses and had a tough stare. This was Ekaterina Karakova in the first year. In the second year she started wrestling with herself: a very strict diet, daily exercise and study. I was certain that she would not make it at that speed. But I was wrong...
}

The good student does not wear glasses, is slim, fit, good-looking and hard-working - and has the self-discipline to shape him- or herself according to this ideal. Discipline becomes linked to ideas of female beauty, which are grafted onto women's bodies. The article continues to describe how Ekaterina, once the ugly wallflower, now is the prototype of a highly successful businesswoman, implying that this is due to the stringent regime she has imposed on herself. Submitting to discipline enhances the market value of student bodies by producing subjects that are able to outperform competitors in the job market. 
Ekaterina calls MGIMO a comme il faut which trains students to conform to certain standards and live a certain way of life. Whenever she recruits personnel for her company, she immediately recognises MGIMO graduates by 'the way they dress, they behave, they talk. I would call this understanding how to live, and live beautifully, which is what they also teach you at MGIMO'. More than simply teaching knowledge, MGIMO thus also teaches students a particular way of life. This dual move creates docile bodies that not only perform their academic duties and submit to educational routine but also boast an enhanced utility to be successful in the economy. The siren's song of the disciplinary regime is the promise of a position in the societal elite, just as Ekaterina has achieved it.

While Foucault's analysis of discipline finds correspondence in many of the educational routines at MGIMO, painting MGIMO as a comprehensive and unitary educational apparatus would gloss over the different ways in which discipline works upon different students and the instances where it breaks down. In one lecture, the professor was dictating references and I did not manage to catch the names of some Russian authors. As she was dictating at a rapid speed, I decided to copy the references from another student afterwards and just sat listening. This incited her dismay and she reprehended me for not writing down what she read out: 'Do you think that you don't need this, young man? Write!' Just a few minutes later, however, the same professor accepted a phone call in front of the students during the lecture. Apparently, her young daughter had just come home from school and rang her up to tell her that she had safely arrived. At this moment the lecturer stepped out of the educational context and the requirements of discipline to act in a completely private context. After finishing the conversation she carried on with her lecture as if nothing had happened.

The disciplinary regime also does not apply to all students and at all times in equal fashion. In particular, students develop strategies of sidestepping subjectivation through the 
educational apparatus. Some students live up to the necessities of the disciplinary regime, but do not subscribe and become complicit with it. Ljuba, for example, says:

I often see studying here like a game: you have to play according to the rules to be able to win.

Understanding education as a game allows students to circumvent subjectivation, because being successful then becomes a matter of picking a winning strategy; it does not require the full submission to disciplinary techniques. Playing a game always allows to opt out, break the rules and go back to 'real life'. Students who 'play education' conform to the requirements of presence, hard work, diligence and studiousness, they pragmatically accept the authority of lecturers, but they do not become what Foucault calls 'a subjected body' (Foucault 1979 [1975]:26) through education.

Moreover, the subjectivating power of disciplining works to different degrees with different groups of students. Those students who pay tuition fees, the so-called dogovorniki, do not depend as much on good academic performance as those who receive stipends. Dogovorniki are endowed with what Bourdieu calls economic capital and are therefore not as dependent on the acquisition of cultural capital through university education as their classmates from less well-endowed families (cf. Bourdieu 1996 [1989]:336ff). For this reason, there is less urgency for them to submit to the disciplinary regime in order to receive an academic degree. Economic capital can also act as a substitute for discipline. This happens when students pay their fellow students or professional ghostwriters, for example, to complete assignments for them. Not everyone, then, experiences subjectivation in equal measure.

\section{Producing objective knowledge}

With Foucault, disciplinary practices and the production of docile bodies at an educational institution are always bound up with the constitution of knowledge and regimes of truth. 
Truth is created through multiple forms of constraint as they operate within educational institutions. It is a complex system of ordered procedures for the production, circulation, regulation and distribution of knowledge statements (Foucault 1980). Foucault argues that a truth regime consists of

the mechanisms and instances which enable one to distinguish "true" and "false" statements, the means by which each is sanctioned; the techniques and procedures accorded value in the acquisition of truth; the status of those who are charged with saying what counts as true (Foucault 1980:131).

Educational institutions instantiate truth regimes through a wide repertoire of techniques to regulate what counts as true knowledge, who is able to teach true knowledge and how it is acquired. Making knowledge appear natural and objective, truth regimes both enable and disguise the subjectivating power of discourse. They enable it by reducing the undecidable to the decidable thus mapping out subject positions and they disguise it by shutting out the contingency of knowledge and substituting it for a singular truth.

Testing and evaluating knowledge through exams is one central technique through which knowledge is fashioned with objectivity. The first exam students have to pass at MGIMO is the entrance exam. While a significant part of the entrance exam covers foreign language proficiency, subjects like geography or history are geared towards the reproduction of facts and figures. In geography, typical questions are of the following kind:

1. Political and economic geography of Russia

a. Change of political and economic geography in comparison to the Soviet Union. Territory, land and marine boundaries, Russia in the CIS (Commonwealth of Independent States).

b. State structure of Russia. 
2. Political map

Indicate on a blank map the member states of OPEC, specify their form of government and territorial structure.

By and large, successful performance in the entry exam is dependent on the meticulous accumulation and reproduction of facts and figures. This is similar to the structure of exams during the course of studies. It is not uncommon that there is a complete list of possible questions for the end-of-term exams available from the lecturers and preparation for the exams is geared towards the knowledge canon demarcated by this list. Asking students mainly to reproduce this knowledge turns exams into arbiters of objectivity, especially since academic performance is tied to the 'correct' reproduction of knowledge. In the classes students are required to be able to immediately retrieve the knowledge they have stored. It is not uncommon for them to be called up by the lecturer and to be catechised with questions of the following kind:

What is the definition of GDP? What is the total amount of Russia's GDP? How many hectares of arable land per capita in Russia? How many litres is a barrel? And so on.

The necessity to give immediate and unambiguous answers in such situations fosters the accumulation of facts and figures; as a mainstay of academic performance this kind of knowledge acquisition is held in high regard by lecturers and students alike and rewarded, through disciplining practices, with good grades. The immanent logic of urgency favours the recycling of the same patterns of argumentation. Resorting to similar answer schemata allows satisfying the demands of examination - to give an immediate answer to any possible question - at the lowest cost. Knowledge, then, becomes an object to be mastered through drill and accumulated - the more the better. 
It is not only the disciplinary technique of exams, however, that fashions knowledge with objectivity. The presentation of arguments in lectures also relies heavily on seemingly objective facts and figures to support conclusions. One lecturer even argues that the application of natural laws to social and political processes is a highly useful way of doing analysis, because of the similar structure of nature and society: the stability of social systems, the balance of powers, the theory of Pareto distribution can all be explained with the help of laws from the natural sciences. Lecturers sometimes contrast this objective, scientific assessment in political science with the supposedly subjective views and opinions expressed in politics and society. This is reminiscent of scientism and the underlying assumptions are not dissimilar to those of scientific communism, a Soviet variant of political science. Just like in natural science, scientific communism saw society functioning according to universal social laws which allowed an allegedly objective analysis of the regularity of social processes: 'society develops through the operation of objective laws' (Afanasyev 1981:10).

Russia's role in world politics is one of those topics where a lecturer at MGIMO proposes a scientific, objective treatment of the question:

\footnotetext{
Thinking about Russia's place in the world, we will orient ourselves towards simple, scientific things like the share of GDP, the share in world trade, territory, armed forces, the number of warheads and so on. This is not as poetic as Tjutčev or Bunin but it allows, at least, to draw unambiguous conclusions (Lecture 11/7).
}

Such unambiguous conclusions, it is argued, can also be derived from analysing the 'objective core' (Lecture 13/7) of Russian national interests. Arguments and conclusions presented in classes are therefore always based on a meticulous recounting of facts and figures. Collection, analysis and synthesis of the facts at hand are the main instruments of judging international relations. This systematic, ordered account is essential as a procedure 
for geopolitical knowledge to be recognised as legitimate and true. Such analysis is regarded as 'professional' and MGIMO students are taught to follow this example:

I don't know the details of the [diplomatic] talks and that's why I hesitate to comment on this question. You have to know all the details. I don't want to say anything about this topic, because you have to be a professional. ... That's what you will have to do all of your remaining life, if you work professionally: analyse events that are happening and make conclusions and predictions (Lecture 31/1, 18).

This lecturer argues that there is a process of analysis, of accumulating and interpreting facts, through which to validate geopolitical knowledge. Through following such an analytical schema, students can draw objective conclusions. By subjecting them to a whole apparatus of acquisition and reproduction of knowledge, the university turns students into professionals who know how to produce valid truth and eventually become themselves ordained as geopolitical truth-tellers in society.

Bourdieu (1996 [1989]:111) aptly observes that at elite schools 'the material taught is less important in and of itself than what is taught above and beyond this material through the ordeal required for its acquisition'. Through disciplining techniques MGIMO acquires not only the authority to transmit knowledge but it also transforms the nature of knowledge. In the educational process the contingency of knowledge all but disappears. The masses of facts and figures to be consumed and reproduced make knowledge acquisition and accumulation an end in itself. Knowledge can be separated into smaller bits and pieces to be tested by regular examinations. Students are drilled to 'apply' knowledge in the analysis of foreign policy problems. The mastery of details is represented as an important asset of any expert graduating from MGIMO. These mechanisms fashion knowledge with an objective quality and in so doing prepare the ground for the Russian great power project. 


\section{Objectivating Russia as a great power}

We have seen that subjectivation at MGIMO works through numerous techniques that ensure discipline and fashion knowledge with objectivity. This educational apparatus is supposed to form patriotic subjects who identify with Russian national greatness. Indeed, the discourse of Russia as a velikaja deržava - a great power - is pervasive at MGIMO. This discourse has emerged as the dominant geopolitical orientation in Russia since about the mid-1990s and has received much attention in the literature on Russian foreign policy (e.g. Hopf 2005, Lo 2003, Neumann 2008, O'Loughlin et al. 2005, Oldberg 2007, Smith 1999, Tsygankov 2005). Central to the status of a great power is the imagination of Russia as an independent pole of power in a multipolar world politics. Russia is seen as distinct from the West both in cultural values and geopolitical interests and integration into Europe or into Western alliances is not an option, Russia should rather pursue its own path as a Eurasian state between Europe and Asia. Establishing Russia as a great power usually means re-asserting its influence in the so-called Near Abroad, the states of the former Soviet Union. Under Putin, economic prosperity has come to be viewed as an essential element and precondition for bolstering Russia's great power status.

At MGIMO, the discourse of Russia as a great power is bound up with the practices of professional analysis that produce objective knowledge. That Russia will become and must be a great power can be deduced from rational analysis that compiles all necessary facts. This type of analysis is evident from the following extract in which a student argues forcefully (but with a peculiar interpretation of economic theory) to the effect that Russia's economic power is seriously underestimated.

Looking at the different levels of GDP] the question arises whether Russia is really 25 times less important than the US? Or 9 times less important than Japan and so on? There are two approaches. If one counts the GDP according to the exchange rate, Russia is certainly in a 
losing position. Why? Because the role of the currency ... is depreciated. If we calculate that one rouble is a tenth of one dollar, then, correspondingly, the Russian GDP will always be a tenth of the American GDP. ... If, however, we take the difference between the nominal GDP and the GDP by Purchasing Power Parity, then the difference [between Russia and the US] is only five times. If in the first case it is 400 billion per year, then in the second case we already have a trillion. And this already puts Russia among the top five states in the world by GDP. The difference is tremendous.

We say that Russia's GDP is comparable to that of South Korea. But who knows whether South Korea will have such a GDP in ten years' time? Russia's GDP won't decrease, because today's GDP is the minimum of what Russia is capable of, that is, it can only grow from here.

By the way, there is another important characteristic - the structure of GDP. The biggest part of the Dutch GDP, for example, is made up of the non-manufacturing industries. What does this mean? That the Netherlands live on tourism ... It is clear that if the world situation becomes a bit worse, then the GDP ... disappears. But Russian tractors cannot disappear, they will always be sought after. This is why the Russian GDP is more solid.

The major issue here is not with the somewhat flawed logic of explanation or that the economic crisis in 2008 and 2009 has since proved the conclusions of this exposition to be wrong. What is more important is the style in which this analysis is presented. Facts and figures, mixed with a measure of self-confidence ('Russia's GDP won't decrease'), are marshalled and gelled into an analysis that attempts to deduce Russia's great power status from rational analysis. This makes the Russian great power ambitions emerge as an almost inevitable matter of course that results from the analysis of the facts at hand, rather than as a contingent discourse.

Geographical reasoning also plays an important role in justifying Russia's great power status. Russia is taken to have a history of territorial expansion with a concomitant extension of its sphere of influence. It is argued that the country grew significantly in 
territorial size over the centuries and that, because of this huge territory, Russia has always had to defend itself against aggressions from the outside. This geopolitical evolution, it is concluded, makes for the special character of Russia as a 'land empire' and marks out its distinctiveness. A student draws on the case of the Kuril Islands to make the argument that territory is crucial to Russia's self-concept as an empire even today:

\begin{abstract}
Why are the Kuril Islands so important for Russia? They are small islands, only rock, nothing else. What is important for the Russian is the very idea of losing territory. He lives, he was born in a huge country. For him, [spatial] dimensions are very important. The loss of a small territory already causes painful reverberations. Completely imperial ambitions (Aleksandr, International Relations, Year 3, 14/47) ${ }^{1}$.
\end{abstract}

Often connected to this territorial constitution of Russia's great powerness is a particular historical mentality of empire, which is seen to be a central determinant of Russian foreign policy today. Because Russia has always had imperial traditions throughout its long history, it follows that it must remain a great power even today.

In order to be or become such a great power, economic strength is considered indispensable:

When we have completely got back on our feet, when we have acquired that economic power, only then can we dictate our terms (Larissa, International Relations, Year 4, 15/11).

The new emphasis on economic strength is often addressed as a new pragmatism that is replacing the ideological baggage of the Soviet Union:

I think that Russia's position now is pragmatic and ideologically we do not look to anyone specifically. Even economically. In my opinion, the engine of history now is the economy and

\footnotetext{
${ }^{1}$ Parentheses contain the (fictitious) name of the student, the year of study, the department as well as a retrieval code.
} 
not ideology, religion or something else. We are pragmatic and develop the relations with our partners, with those who are ready (Ivan, Year 4, International Journalism, 05/9).

Building up Russia's economic strength is seen as the logical thing to do. It is not dictated by false ideology, but by the objective laws of competition in the world economy. In this way, ideology is set up as a contrast to economy: ideology is an irrational belief, whereas the economy is a quasi-natural necessity. Scientific communism, which claimed for itself to represent an objective science, is discredited here as an untenable ideology, whereas economic strength is re-instituted as the new objectivity. Ironically, placing an emphasis on the economy is sometimes justified by drawing on the same doyens of communism whose 'ideology' is disdained:

What is the reason for the disintegration of the Soviet Union? It is because the leaders of the Soviet Union did not understand that when the economy is starting to stall, when it stops working, then one has to direct all attention not towards extending one's sphere of influence, but towards the economy. Because a strong economy means a strong politics, as Marx already said. Now we no longer believe in Marx, but this postulate remains and it is a correct statement (Tatjana, Year 4, International Relations, 08/11).

Putting economic growth first to leverage the re-emergence of a strong Russia is interpreted as an objective necessity. Not only is it a law ascribed to Marx, but it is also thought to become evident from looking at what makes the world go round. That a strong Russia needs to be strong economically becomes an undisputed reality by anchoring it in the certainties delivered by a pragmatic analysis of supposedly patent facts.

\section{Disrupting Russia as a great power}

MGIMO's close connection to the Russian Foreign Ministry and its explicit mission to educate future elites to serve Russia are reflected in an educational apparatus through 
which the discourse of Russia as a great power is fashioned with objectivity. Yet, education at MGIMO is not fully complicit with the creation of geopolitical subjects of a strong Russia. Alongside articulations of strength we find notions that disrupt the great power discourse. When this occurs, the educational apparatus that ensures the production of objective knowledge and the perpetuation of the great power discourse also begins to stutter. The social laws and objective analysis of world politics do not seem to hold anymore, when the discourse of a strong Russia starts to crumble. Challenges to a strong Russia are represented as something irrational, emanating from outside the logical analysis of world politics. They unsettle the hegemonic discourse, exposing the impossibility of a strong Russia, and cannot be explained in the objective terms of analysis taught at MGIMO.

Perhaps the most deeply felt disruption of the great power vision is the collapse of the Soviet Union and the resulting challenge to Russian influence in the countries of the Near Abroad. In describing the relation to the former socialist brother states of the Soviet Union, the use of familial metaphors reflects the deep significance of the forced dissociation that followed the collapse of the Soviet Union:

\footnotetext{
This [collapse of the Soviet Union] is similar to imagining that husband and wife lived together, and lived, and lived, and then got divorced. But the husband still sees himself as the most important, although the wife does not live with him any more, but with someone else. If he continues to behave towards her as if she were still his wife, if he dictates to her, if he imposes his terms on her, this would at least be injudicious (Lecture 61/11).
}

Larissa expresses the common sentiment that 'these are our own, our former countries and relations, after all!' (Larissa, Year 4, International Relations, 15/26, emphasis added). These statements suggest a possessive relationship, quasi-natural bonds that bind the countries of the Near Abroad to Russia. Breaking these bonds is considered as disloyal and 
a breach of trust. This is expressed in the following simile used by one lecturer to describe the break-up between Russia and Ukraine after the Orange Revolution. The lecturer compares Russia's relationship with Ukraine for the transit of natural gas with a man commissioning his friend to sell doors for him:

\footnotetext{
You [Russia] manufacture furniture, doors. But you don't have any time to sell them and you tell your friend [Ukraine]: "Sell the doors for me, I don't have any time to do this." And suddenly your friend all the time returns only half of the value of those doors to you. He finds different reasons, for example that the car broke down. For how long will you tolerate such a friend? (Lecture 61/18).
}

The expected answer to this rhetorical question is, of course: 'not for very long!' Ukraine, and in the same vein all other post-Soviet states going down a similar path, are ostracised as not deserving Russia's friendship. They are portrayed as constantly trying to play on Russia and only pursuing their own benefit while ignoring the age-old bonds of allegiance that tie them to Russia.

Fuelling the tendencies of dissociation from Russia in the Near Abroad, the West is rendered a powerful antagonist to a strong Russia. It wants to keep Russia down and out of international politics, trying to vitiate its re-emergence as a great power.

\footnotetext{
Right now I think that Ukraine and Georgia are like cards which the Western countries, the US among others, play in order to curtail Russia's sphere of influence, overturn its political authority and partly even overturn the country itself (Vasilij, Year 4, International Relations,
} 19/59)

In this articulation of threat we do not find the objective analysis, the meticulous gathering of detail information to then draw a conclusion, that is advocated at MGIMO. It is quite the opposite: a speculation of what might be possible which leads to an ominous feeling of threat. The quality of this threat is precisely that it cannot be pinned down, dissected, 
analysed. This amorphous nature allows it to be linked up with a host of other developments challenging Russia as a great power, gelling into a powerful, unitary antagonist:

[The US] invests money there [the Near Abroad] in order to drag it into its sphere of influence. This is not in Russia's interest. This is again linked to the expansion of NATO in Western Europe. I mean Ukraine, Belarus, the Baltic countries. And the new American army bases in Central Asia. All this affects Russia very badly (Konstantin, 16/51, 4 IR).

Because influence over the Near Abroad is a natural part of the vision of Russia as a great power, when the countries of the Near Abroad start to become irreverent and flirt with other powers, this exposes the impossibility of the great power project. It challenges the naturalised assumption of Russia and the Near Abroad belonging together and therefore appears to be irrational. Drawing the countries of the Near Abroad away from Russia is more than a geopolitical manoeuvre, then. It goes to the heart of Russian self-confidence:

\footnotetext{
Above all, the importance [of the Near Abroad for Russia] is in self-esteem. If we lose our influence in the CIS, in what other countries, in what other regions can we talk about Russia's influence? (Ekaterina, Year 4, International Relations, 04/50).
}

The deviation from the conventional factual style of reasoning underscores the unsettling, emotional dimension of this disruption. It is something that defies and breaks the allegedly natural laws of political explanation and in this vein disrupts the objective style of reasoning prevalent at MGIMO.

But the discourse of Russia as a great power is not only challenged by developments in international politics. It is questioned by much more mundane things such as the construction of Russia as the cultural Other to the West: 
One other thing that I feel sad about is that Russia very often plays the role of a whipping boy (mal'čik dlja bit'ja) in international relations, because Russia's prestige, its image in the eyes of other countries does not improve or only improves very slowly. All of my friends who were in Europe say that Russia is perceived as a monster there (Natalija, Year 3, Political Science, 29/5).

While on the level of formal diplomacy, Russia may seem to be accepted as equal by other states, once it gets down to everyday politics or the mass media, Russia still has to play the role of the bad guy, it is argued. Students see stereotypes about Russia as a culturally backward and underdeveloped country still firmly ingrained in the minds of many people in the West. The geopolitical discourse of a strong Russia is thus disrupted on unfamiliar grounds: it is not in the world of objective analysis of world politics which students have been trained to deal with, but rather in the undisciplined realm of everyday life that a strong Russia seems to be challenged.

Western antagonism and cultural Othering present disruptions to the discourse of a strong Russia. They block Russia from becoming and being recognised as the strong state it wants to be. As this disruption unsettles the great power discourse, it also unsettles the production of objective knowledge. Rational analysis is unable to explain the multiple threats and the cultural exclusion a strong Russia is faced with. One could cite any number of arguments that challenge Russia's great power potential: demographic decline, the over-reliance on natural resources for economic growth, corruption or the violation of human rights. But this would amount to a rational explanation to a phenomenon that is considered irrational, because it contests the objectivity of the great power discourse. The seemingly irrational impossibility of the Russian great power project can only be expressed by resorting to emotional and figurative speech, by constructing similes and drawing on everyday experience. This underscores the tight coupling of educational practices and the formation 
of geopolitical subjects: just as the educational apparatus fashions the project of Russia as a great power with objectivity, the moments when this discourse experiences disruption are perceived as irrational, eluding the disciplining practices of the university.

\section{Conclusion}

\footnotetext{
Because you not only have to know what happens in every country, who is in power and so on, but you also have to know the situation of the youth, the situation of education in that country. Because this is like a photograph of what we have to expect from that state (Lecture at MGIMO, 3 September 2005, 61/17).
}

Looking at the situation of education in a country can provide, at least to some degree, a glimpse of the future. Educational institutions reproduce the decision-makers of tomorrow and fashion them with the geopolitical knowledge that may accompany them for a significant part of their lives. The implication of schools and universities in state development and in the formation of citizen-subjects opens rich opportunities for examining constructions of world politics. Knowledge about boundaries and territories, sovereignty and separatism, security and conflict is taught and reworked in education. Interpretations of a nation's place in the world are crucial to making world politics understandable in the classroom and may remain ingrained in students' minds and shape behaviour for decades. In this sense, education, as Jones (2007:325) remarks, has the potential to become both a builder and a product of global politics.

This paper has sought to tease out the practices of subject formation in international relations education. To understand the production of geopolitical subjects at the Moscow State Institute of International Relations (MGIMO) it is not enough to look at geopolitical representations of Russia's role in world politics. This would not explain how and why the geopolitical discourse of a strong Russia works at MGIMO - and where it is disrupted. We 
also need to take into account the myriad practices of disciplining and contestation of the educational apparatus and the knowledge it produces. The three main parts of this paper therefore belong inevitably together: the production of Foucault's 'docile bodies' is the precondition for establishing truth and objective knowledge, which, in turn, is intertwined with the geopolitical discourse of a strong Russia. Each of these aspects is a central component in the situated analysis of geopolitical subject formation.

An international political sociology of education therefore cannot stop at examining textbooks and other educational material. For the disciplinary mechanisms of education and their implication in the formation of geopolitical subjects do not feature in textbooks. Only a situated perspective on geopolitical discourses can tease out how geopolitical subjectivation works on the ground, how it produces docile bodies and where it fails to do so, how it replicates the official discourse and where it diverges from it. This spells out the case for a perspective that takes seriously the practices involved in the education of geopolitical subjects. 


\section{References}

Afanasyev, Victor. (1981) Fundamentals of Scientific Communism. Moscow: Progress Publishers.

Agnew, JoHn. (2007) Know-Where: Geographies of Knowledge of World Politics. International Political Sociology 1(2):138-148.

AŠIn, GENNADIJ K. (2002) Ėlitnoe Obrazovanie V Menjajuščemsja Mire [Elite Education in a Changing World]. In Elitnoe Obrazovanie: Mirovoj Opyt I Model' MGIMO [Elite Education: Global Experience and the Model of MGIMO], edited by Gennadij K. Ašin, and Sergej A. Kravčenko. Moscow: MGIMO.

BAll, StePhen J., ed. (1990) Foucault and Education: Disciplines and Knowledge. London: Routledge.

BAR-GAL, YoRAM. (1993) Boundaries as a Topic in Geographic Education: The Case of Israel. Political Geography 12(5):421-435.

Bourdieu, PIERre. (1996 [1989]) The State Nobility: Elite Schools in the Field of Power. Stanford: Stanford University Press.

DALE, Roger, ed. (1981) Education and the State: Schooling and the National Interest. Barcombe: Taylor and Francis.

Dean, Mitchell. (1999) Governmentality: Power and Rule in Modern Society. London: Sage.

ECKL, JULIAN. (2008) Responsible Scholarship after Leaving the Veranda: Normative Issues Faced by Field Researchers - and Armchair Scientists. International Political Sociology 2(3):185-203.

Foucault, Michel. (1971) L'ordre Du Discours. Paris: Gallimard.

Foucault, Michel. (1979 [1975]) Discipline and Punish: The Birth of the Prison. New York: Vintage.

Foucault, Michel. (1980) Truth and Power. In Power/Knowledge: Selected Interviews and Other Writings 1972-1977 by Michel Foucault, edited by Colin Gordon. New York: Pantheon, pp. 109-133.

Foucault, Michel. (1982) The Subject and Power. In Michel Foucault: Beyond Structuralism and Hermeneutics, edited by Hubert L. Dreyfus, and Paul Rabinow. Chicago: University of Chicago Press, pp. 208-226.

Foucault, Michel. (1991) Governmentality. In The Foucault Effect: Studies in Governmentality, edited by Colin Gordon, Graham Burchell, and Peter Miller. Chicago: University of Chicago Press, pp. 87-104. 
Fuller, DunCan. (1999) Part of the Action or 'Going Native'? Learning to Cope with the 'Politics of Integration'. Area 31(3):221-227.

GreEn, A. (1990) Education and State Formation: The Rise of Educational Systems in England, France and the USA. New York: St. Martin's Press.

Haraway, Donna. (1991) Simians, Cyborgs and Women: The Reinvention of Nature. Routledge: London.

HARRINGTON, BROOKE. (2002) Obtrusiveness as Strategy in Ethnographic Research. Qualitative Sociology 25(1):49-61.

Herb, Guntram H. (2004) Double Vision: Territorial Strategies in the Construction of National Identities in Germany, 1949-1979. Annals of the Association of American Geographers 94(1):140-164.

Hopf, TED. (2005) Identity, Legitimacy, and the Use of Military Force: Russia's Great Power Identities and Military Intervention in Abkhazia. Review of International Studies 31(S1):225-243.

IVAnOva-GalitsinA, ANNA. 10 May 2000. A Training Ground for Tomorrow's Elite: MGIMO. Financial Times, 8.

JACKSON, PATRICK ThadDEUS. (2008) Can Ethnographic Techniques Tell Us Distinctive Things About World Politics? International Political Sociology 2(1):91-93.

Jones, PHILIP W. (2007) Education and World Order. Comparative Education 43(3):325337.

Kuus, MerJe. (2009) Cosmopolitan Miltarism? Spaces of Nato Expansion. Environment and Planning A 41:545-562.

LANE, DAVID. (1996) The Transformation of Russia: The Role of the Political Elite. Europe-Asia Studies 48(4):535-549.

Lo, Bobo. (2003) Vladimir Putin and the Evolution of Russian Foreign Policy. Chatham House Papers. Blackwell: Oxford.

Marshall, JAmes D. (1990) Foucault and Educational Research. In Foucault and Education: Disciplines and Knowledge, edited by Stephen J. Ball. London: Routledge, pp. 11-28.

MCNicol Jardine, Gail. (2005) Foucault \& Education. New York: Peter Lang.

Megoran, Nick. (2006) For Ethnography in Political Geography: Experiencing and ReImagining Ferghana Valley Boundary Closures. Political Geography 25(6):622640. 
Mitchell, Katharyne. (2003) Educating the National Citizen in Neoliberal Times: From the Multicultural Self to the Strategic Cosmopolitan. Transactions of the Institute of British Geographers 28(4):387-403.

Müller, MARTIN. (2008) Reconsidering the Concept of Discourse in the Field of Critical Geopolitics: Towards Discourse as Language and Practice. Political Geography 27(3):322-338.

Müller, Martin. (2009) Making Great Power Identities in Russia: An Ethnographic Discourse Analysis of Education at a Russian Elite University. Zürich: LIT.

NeumanN, IVer B. (2002) Returning Practice to the Linguistic Turn: The Case of Diplomacy. Millennium: Journal of International Studies 31(3):627-651.

Neumann, IVER B. (2008) Russia as a Great Power, 1815-2007. Journal of International Relations and Development 11(2):128-151.

Ó TuATHAIL, GEARÓID. (1999) Understanding Critical Geopolitics: Geopolitics and Risk Society. Journal of Strategic Studies 22(2-3):107-124.

O'Loughlin, John, Gearóid Ó Tuathail, and Vladimir Kolossov. (2005) Russian Geopolitical Culture and Public Opinion: The Masks of Proteus Revisited. Transactions of the Institute of British Geographers 30(3):322-335.

Oldberg, Ingmar. (2007) Russia's Great Power Ambitions and Policy under Putin. In Russia: Re-Emerging Great Power, edited by Roger E. Kanet. New York: Palgrave Macmillan, pp. 13-30.

PAASI, ANSSI. (1999) The Changing Pedagogies of Space: Representation of the Other in Finnish School Geography Textbooks. In Text and Image: Social Construction of Regional Knowledges, edited by Stanley D. Brunn, Anne Buttimer, and Ute Wardenga. Leipzig: Institut für Länderkunde, pp. 226-237.

Popkewitz, Thomas, ed. (1997) Foucault's Challenge: Discourse, Knowledge and Power in Education. New York: Teachers College Press.

Pouliot, Vincent. (2008) A Logic of Practicality: A Theory of Practice of Security Communities. International Organization 62(2):257-288.

RoŽKOV, IGOR'. (2007) Interview.

Smith, Graham. (1999) The Masks of Proteus: Russia, Geopolitical Shift and the New Eurasianism. Transactions of the Institute of British Geographers 24(4):481-494.

SPRING, JoEL H. (2004) How Educational Ideologies Are Shaping Global Society: Intergovernmental Organizations, NGOs, and the Decline of the Nation-State. Mahwah: Lawrence Erlbaum.

Stoddart, Kenneth. (1986) The Presentation of Everyday Life: Some Textual Strategies For "Adequate Ethnography". Urban Life 15(1):103-121. 
TemnickiJ, AleKsandr L. (2002) Sociologičeskij Monitoring Processa Polučenija Elitnogo Obrazovanija (Na Primere Studentov MGIMO) [Sociological Monitoring of the Process of Elite Education (the Case of Students at MGIMO)]. In Elitnoe Obrazovanie: Mirovoj Opyt I Model' MGIMO [Elite Education: Global Experience and the Model of MGIMO], edited by Gennadij K. Ašin, and Sergej A. Kravčenko. Moscow: MGIMO, pp. 189-223.

TorkunOv, A. V. (2004) MGIMO-Universitet: Tradicii I Sovremennost': 1944-2004. (MGIMO-University: Traditions and Present: 1944-2004). Moscow: Moskovskie Učebniki i Kartolitografija.

Tsygankov, ANDRei P. (2005) Vladimir Putin's Vision of Russia as a Normal Great Power. Post-Soviet Affairs 21(2):132-158.

Usher, RoBin, and Richard EdWARDS. (1994) Postmodernism and Education. Abingdon: Routledge.

VRASTI, WANDA. (2008) The Strange Case of Ethnography and International Relations. Millennium: Journal of International Studies 37(2):279-301.

White, Stephen. (2007) Elite Opinion and Foreign Policy in Post-Communist Russia. Perspectives on European Politics and Society 8(2):147-167. 